\title{
Cross-National Patterns of Labor Force Withdrawal*
}

\author{
Timothy M. Smeeding \\ Center for Policy Research \\ Syracuse University \\ Syracuse, NY 13244-1020 \\ (315) 443-9042 (phone) \\ (315) 443-1081 (fax) \\ tmsmeed@maxwell.syr.edu \\ and \\ Joseph F. Quinn \\ Department of Economics \\ Boston College \\ Chestnut Hill, MA 02167 \\ (617) 552-4623 (phone) \\ (617) 552-2308 (fax) \\ joseph.quinn@bc.edu
}

June 1997

*This paper was presented at the Fourth International Research Seminar of the Foundation for International Studies on Social Security (FISS), on June 15-17, 1997 in Sigtuna, Sweden and at the European Society for Population Economics annual conference, June 19-21, 1997 in Essex, Great Britain. The authors would like to thank Katherin Ross, Esther Gray, Kati Foley, and Kevin Cahill for their help in preparing this manuscript. The paper was supported in part by funds from the National Institute on Aging under grant \#PO1-AG09743. 


\section{Introduction}

During the post-war period, life expectancies, age distributions and retirement patterns have changed significantly in the developed, industrialized nations. Between 1950 and 1990, for example, the life expectancies for men and women in the United States increased by 6.1 and 7.3 years. Similar at birth changes, and often larger ones, can be found in other OECD countries (U.S. Bureau of the Census 1993, Figure 3.1). At the same time, men (and less often women) have been leaving the labor force earlier and earlier in these same countries (OECD 1995a, Table 2.1; OECD 1996, Table A2). The result has been an increasing period of labor market inactivity at the end of the life cycle. As these nations age, the ratio of workers to retirees is falling, presenting potential fiscal difficulties for these governments and economies (Boivenberg and van der Linden 1997).

In the United States, several public policy initiatives have been undertaken to encourage more work and later retirement among older Americans. Labor force participation data over the past decade suggest that these policies may be working — the early retirement trend seems to have stopped. The purpose of this paper is to analyze retirement patterns in the United States and six other OECD countries to compare their levels and to see if any changes in trends can be discerned over recent years.

In order to investigate this issue, we will to focus on differences and similarities between labor force participation and several other concepts of retirement. Many people view labor force withdrawal and retirement as synonymous, but recent research has shown that retirement patterns are many and varied. The purpose of this paper is to examine these issues with an eye toward answering several questions: 
- How does one measure retirement across many nations?

- Has their been change in the age of retirement, however defined, over time?

- Does work stoppage mean receipt of retirement income, and vice versa?

- Does retirement mean full work stoppage or a more gradual withdrawal from the labor market.

- Finally, does retirement mean impoverishment?

This work builds on previous research by both authors (Smeeding 1992; Quinn 1997). We will argue that retirement and labor force withdrawal mean different things to workers and to family economic status depending on the nature of each nation's disability, unemployment and retirement system, and on their labor market institutions.

We begin by reviewing some of the potential uses and operational meanings of the term "retirement" and the seismic demographic transition which prompts wide policy interest in this topic (Section II). We then describe our data and variables (Section III), results (Section IV) and conclusions (Section V). The bottom line is in one sense straightforward; labor force withdrawal is still continuing at early ages in most wealthy nations. Unless we find ways to induce older workers to remain in the labor market longer, the demographic tsunami of the baby boom will create severe fiscal problems for most of the nations examined here. In another sense, this paper is more complicated. "Retirement" is a very complex issue which may require different definitions depending on the policy issue at hand.

The results of this paper are based on the Luxembourg Income Study (LIS) database. LIS offers a choice of 25 nations where labor force withdrawal can be examined. Here we chose seven: Australia, Canada, the United States, The Netherlands, Sweden, the United Kingdom, and Germany. We chose these seven for several reasons. 
First, they are among the economically most important nations within LIS. Only Japan (where the data are not available) and France and Italy (where the data are old) are alternatives on these grounds.

Second, these nations represent a broad range of experiences with respect to the labor force participation of male workers nearing traditional retirement age. In 1995, only 42 percent of men aged 55 to 64 in The Netherlands were still in the labor force, compared to about 60 percent in Australia, Canada, West Germany and the United Kingdom, 66 percent the United States and 70 percent in Sweden. These fairly well span the range of national experiences found in OECD nations (Figure 1). Only Italy (30 percent) has a lower participation rate at these ages than does The Netherlands, while Norway and Sweden have the highest participation rates except for Japan.

Third, these seven nations were first visited on this issue by Smeeding (1991a, 1992) and we now return to them for an update. Finally, we are Americans presenting this paper in both Sweden and the United Kingdom where there is interest in these issues.

\section{Patterns Retirement, Demographics and Public Policy in Rich Nations}

The term "retirement" or "retired" is often used in social science research on public policy and the aged. One would be hard pressed to find a less murky term or one with fewer questions

attached. Is retirement defined by labor supply, receipt of retirement income, or by selfdescription? Is it a "state" behavior or a transitional behavior? Does it connote social uselessness and lack of productivity, or the pursuit of other types of "productive aging" activities, such as volunteer work or travel? From a social policy point of view, does retirement mean poverty and the inability to meet basic economic needs, or a comfortable standard of living? Is retirement a tool of social and business policy which can be used to induce older workers out the labor market and 
thereby create new job openings for younger workers? Do workers retire willingly or unwillingly? Is health a major factor in the retirement decision? Does withdrawal from the labor market mean receipt of pension benefits or other benefits? What other benefits are used to support retirees? And once older workers leave their lifetime jobs do they continue to work? If so, where, doing what, and for how long? Does receipt of retirement benefits mean total stoppage of work or movement to a less time intensive "bridge job" to ease the transition? In short, how one defines retirement has a lot to do with the uses to which one would want to make of the term. And our use is to highlight public policy issues, particularly those that affect the social cost of retirement.

\section{Demographic Change: Experiences of Nations}

The age distributions of the populations of the OECD nations are changing dramatically. As life expectancies increase and the post-war baby boom cohorts age, the proportions of the populations that are of traditional retirement age are increasing and will continue to do so. In 1960, only 9.4 percent of the OECD population was aged 65 or over. Today, the OECD average is between 13 and 14 percent and well over 14 percent in the European countries. By 2030, when the last of the baby boomers will have turned age $65,22.5$ percent of the OECD population is projected to be aged 65 or older (and 10.4 percent will be aged 75 or older). Between now and 2030, percentage aged 65 or older in the United States will have increased by 75 percent, from 12.5 to 21.9 percent. Several nations, including Germany, Italy, Japan, and The Netherlands, will have over 25 percent of their populations aged 65 or older (OECD 1996, Table A2).

Figure 2 shows the percentage of the populations aged 65 or older at ten year intervals between 1990 and 2030 for the seven OECD countries whose retirement trends are discussed in this paper. Among these seven countries, the experience of the United States was at the low end in 1990; it had a larger percentage aged 65 or older than did Australia or Canada, about the same 
fraction as The Netherlands, but a substantially lower percentage than Germany, Sweden, or the United Kingdom. By 2030, however, only Australia is projected to have a lower percentage than the United States. In fact, several Western European countries are more than two decades ahead of the United States on the aging curve. Germany, Sweden, and the United Kingdom all had substantially higher proportions of people aged 65 or older in 1990 than the United States is projected to have in 2010 .

While all countries will face these demographic pressures, not all have responded or will respond in the same way, particularly regarding labor force initiatives and/or incentives. We compare some of their experiences here. We start with the United States, which in some ways faces the least demographic pressure, but where some early policy initiatives are already underway.

\section{The American Experience}

The aging of the population in America, modest as it may be compared to the experience of many other OECD nations, is having important implications for the financing of Social Security (Old Age, Survivors, and Disability Insurance (OASDI)), our largest and most important social insurance program. Because the baby boomers (defined as those born between 1946 and 1964) are currently in their prime working years, the age distribution retains a rough triangular shape, with about 3.3 workers supporting each retiree. Social Security revenues (primarily the proceeds of a 12.4 percent payroll tax, split evenly between the employer and the employee) exceed expenditures by about $\$ 70$ billion per year, and the Social Security Trust Fund, the recipient of these surpluses, is increasing rapidly. Beginning about 2020, however, under current tax and benefit rules, expenditures will exceed revenues, and the Trust Fund reserves will have to be used to make up the difference. Were no changes to be made, the OASDI Trust Funds would be depleted, and Social Security technically bankrupt, by 2029, about three decades from now. 
America, as most other industrialized nations, has witnessed a significant increase in early labor force withdrawal during the post-war period. Whereas about one out of every two American males aged 65 or older was working in 1950, only one in six are employed today. This decline in work effort and the simultaneous increase in early receipt of Social Security benefits will accentuate the impacts of population aging on Social Security finances. Because of the impending bankruptcy of our primary social insurance system, some important changes in Social Security rules and in retirement behavior are inevitable. Some combination of revenue increases and benefit decreases or delays are necessary to bring Social Security back into long-range actuarial balance. The longer we wait to make such changes, the greater are the changes that must be made.

In the United States, several important public policy initiatives have already been enacted to encourage later retirement by older Americans. Mandatory retirement, which once covered about half of the work force, was first delayed from aged 65 to 70 (in 1978) and then outlawed altogether (in 1986). The amount of money that Social Security recipients could earn each year without losing benefits was increased, and is now indexed to wage growth. (For those aged 65 to 69 , this "exempt amount" is scheduled to increase by much more than wage inflation, from $\$ 13,500$ in 1997 to $\$ 30,000$ in 2002.) The age of eligibility for "normal benefits," which has been age 65 since the beginning of the program in the late $1930 \mathrm{~s}$, is scheduled to rise to age 66 early next century and then, after a 12 year hiatus, to age 67 . This will not only lower the benefits of those who continue to retire at age 65 , but will also send an important societal message about retirement timing. Finally, the financial reward for delaying receipt of benefits beyond the "normal age" is being increased, from 3 percent to 8 percent per year of delay, thereby encouraging additional work by older Americans. 
On the private sector front, there has been a steady decline in the relative importance of defined-benefit (DB) employer pension plans (in which pension rules determine the dollar benefit that the worker will receive, usually as a function of years of service and terminal salary), and a simultaneous increase in defined contribution (DC) plans (in which the employer guarantees only a contribution to the worker's retirement account, the size of which determines the annual benefit at retirement) (EBRI 1995). Considerable research has shown that DB plans often incorporate strong retirement incentives (or work disincentives) beyond some age, usually the earliest age of eligibility (Kotlikoff and Wise 1989; Quinn, Burkhauser, and Myers 1991). Many DB plans penalize those who stay on the job past some optimal point, by reducing the present discounted value of the expected benefit stream with each additional year on the job. Econometric evidence indicates that people respond to these incentives. DC plans, in contrast, are age-neutral, and have no such work disincentives. Although DB plans remain important in America, the rise in the extent of DC plans is slowly reducing the importance of these age-specific retirement incentives.

There is some evidence that these public and private policy changes are working. Casual empiricism suggests a break in retirement patterns in the mid-1980s. Labor force participation rates (one definition of "retirement") of older American men declined steadily form 1950 until about 1985, but have been flat since then, and there is even a suggestion of a slight increase over the past few years.

Figure 3 provides clear evidence of a break in the prior trends in the United States. It shows, for men aged 55 to 59 through aged 70 and over, both the actual labor force participation rates and predicted rates based on a simple extension (from a time series regression) of the 1964 to 1985 age-specific time trends. The differences between the actual and predicted values from 1986 on illustrate the new regime. Participation rates since 1986 have been higher (and often 
substantially higher) than the prior trend would have predicted. There is even a suggestion of a slight increase over the past few years.

The changes in the long-term trends are consistent with the policy changes described above, indicating that changing retirement incentives by means of changing policy parameters may have an important impact on behavior. However, determining the actual causes of these changes in trend is difficult, and has been muddied by the very strong economic performance of the United States economy over the past five years, during which the overall unemployment rate dropped from 7.5 percent in 1992 to 4.8 percent today. This macroeconomic strength may have increased the desire and the ability of older Americans to stay on the job longer than they would have in the past, and may therefore have contributed to the change in trend noted above. However, the break in behavior for men in all age groups began in the mid-1980s and has persisted since then despite a recession (1990-1991). Thus, secular forces as well as cyclical forces are at work here.

\section{The American Concept of Retirement}

In America, "staying on the job" can mean many things. For some, it means delaying departure from a career position. But for others - a substantial minority - it means leaving the career job (often when employer pension incentives dictate), but staying in the labor force in a new position, often part-time and sometimes as a self-employed worker. Many Americans, although still not most, retire gradually, in stages, utilizing "bridge jobs" between full-time career employment and complete labor force withdrawal (Quinn 1997). This makes the concept of "retirement" difficult to define.

American retirement definitions span the range outlined above. For some researchers, retirement means complete labor force withdrawal-the absence of earnings. For others, it is defined by the receipt of retirement income, either Social Security or benefits from an employee 
pension plan, regardless of whether the individual is still working or not. Others look for a significant decline in hours or earnings, or a job switch late in life. Still other analysts utilize a subjective definition-how respondents in a survey described themselves. These different definitions can lead to different conclusions about the proportion of a population that is "retired" at any given age or point in time.

\section{Experiences of Other Nations}

Figure 4 illustrates how trends in labor force participation among men aged 55 to 64 have changed in the nations studied here. In Figure 1 we saw that participation rates are currently lowest in The Netherlands (42 percent) and highest in Sweden (70 percent). While these different participation rates can be corroborated from other sources, the trends may be more important than the level. In fact, participation rates for these men dropped significantly in all seven countries during the 1970 to 1985 period, by an average of about 0.6 points per year in Sweden, by about 1.0 point per year in the United States and Canada, and even more in West Germany $(-1.34$ points/year), Australia (-1.64 points/year) and The Netherlands (-2.24 points/year). During the past decade, however, participation rates for men aged 55 to 64 were almost unchanged in Australia, West Germany, and the United States. They continued to decline, although more slowly than prior to 1985, in The Netherlands. In Sweden and the United Kingdom, the rate of decline continues at about -0.5 points per year, close to the Dutch trend since 1985 . Only in Canada, which currently has the highest rate of labor force exit, do we find an increasing trend toward early retirement.

Labor force withdrawal is only one issue involved in the fiscal cost of retirement, outlays for public social retirement and related programs are also important. For instance, Table 1 provides some cross-national evidence for public pension costs and standard age of entitlement to 
public pensions courtesy of the OECD (1996). The first contrast of obvious interest is the limited usefulness of the standard age of retirement as a predictor of retirement behavior. While standard age of benefit receipt does have some effect on retirement as noted by "spikes" in labor force leaving behavior, considerable labor force withdrawal has already occurred by them.

While all seven of our nations have the exact same age of normal retirement for men (of these only the United Kingdom has a lower age for women), the costs of public pensions as a fraction of GDP very enormously across these nations. Australia has no social insurance system but rather an income-tested pension in old age which guarantees most workers about 60 percent of the median overall level of disposable income. Thus, benefits are very targeted at the bottom of the distribution and cost only about 2.6 percent of GDP in 1995. This allows the Australians to control their outlays and they predict only an 11.5 percent change by 2030 when the number of aged are expected to peak. The United States and the United Kingdom faced the next lowest levels of program costs in 1995. The United Kingdom forecasts a relatively modest 22 percent rise in pension claims by 2030. The British achieve much of their savings by offering private accumulation pension plans (SERPS) in addition to a modest first tier social retirement benefit plan. The Americans anticipate a steep 61 percent increase in their social retirement costs. While many Americans regard as cataclysmic the rise in public pension outlays expected over the next century (e.g., Peterson (1996)), America will only spend 6.6 percent of GDP for this purpose by 2030, third lowest and still far below 1995 levels of outlay in Germany and Sweden. The Canadians and Dutch face the largest increases in outlays. While the Canadians will still be below 10 percent of GDP in outlays in 2030 , they face a 73 percent (3.8 point) rise in total outlays over the next 35 years. The Dutch will see their outlays nearly double from 6.0 to 11.2 percent of GDP. Financially, the Germans and the Swedes begin with 1995 pension to GDP rates of over 11 
percent, far above the other nations examined here. ${ }^{1}$ They are expected to further expand another 3.2 (Sweden) to 5.4 (Germany) percentage points beyond these already high levels. The bottom line is that with the exception of Australia, each of these nations is facing a large increase in the fiscal burden of pension outlays over the next 35 years if current policies are not changed.

Because policies will likely be changed, these forecasts are not likely to occur. In fact, even the 1995 figures are in some ways just "estimates." For instance, none of the figures in Table 1 include the cost of "early retirement" benefits that fall under "disability," "extended unemployment" or "unemployment retirement" schemes. Given low rates of male labor force participation prior to age 65, the standard age of retirement in all of these nations, something else must be supporting early labor force departures. These issues can be faced as they were in the United States where there is evidence of labor force turnaround. But cost forces are pushing up the retirement burden in two directions: from below (early retirement) and from above (life expectancy). As we mentioned earlier, overall lifespan and life expectancy at age 65 has been growing in all nations. According to Preston (1996), the United States social retirement actuaries are liable to be seriously underestimating expected gains in life expectancy at older ages over the next 30 to 40 years. If he is correct more generally, all nations will be facing even larger burdens in 2030 than those forecast by OECD because of underestimates of life expectancy. From 1935 to 1985 , added years of life expectancy at age 65 all by themselves produced a 28 percent increase in social pension outlays (Smeeding 1991b). Finally, increases in public health care costs due to an aging society have not been figured into these estimates. Rough estimates from the OECD (1996, Table 3.3) indicate that population aging could add another 1.5 to 2.5 percentage points of GDP to the cost of providing health care for these elders. What is now painfully clear to each of these nations is that the fiscal costs of an aging society are growing rapidly (OECD 1996). 


\section{Social Policy and Retirement}

Labor force withdrawal at older ages depends on both demand and supply factors. On the demand side, the productivity of older workers and pay practices (age-earnings profiles) are important, as is the macroeconomic strength of the economy. Government policies to protect against age discrimination, firing rules, and laws against mandatory retirement all limit the ability of employers to affect retirement decisions.

Government social insurance programs can have significant impact on labor supply decisions, and may help explain why actual retirement ages are often so much lower than official standard ages. In fact, many European workers claim retirement at much earlier ages. When asked their status on the 1992 European Labor Force Survey, 65 percent of Germans, 56 percent of Dutch, and 89 percent of British aged 60 to 64 list themselves as "retired." The figures for men aged 55 to 59 were 39 percent in Germany, 29 percent in The Netherlands, and only 17 percent in the United Kingdom (Theeuwes 1997).

On the income support side, three different types of policies are used to bridge the income gap between job departure and full old age social retirement benefits. In Germany, The Netherlands, the United Kingdom, Sweden, and Australia, the unemployment insurance system has special provisions for extending unemployment compensation until the official age of retirement. In Germany, The Netherlands and Sweden, this is even called an "unemployment pension." However, "unemployment retirement" is not always separately identified from "unemployment insurance." Because much of unemployment insurance may be cyclical as well, receipt of unemployment insurance may or may not be used as a bridge to retirement.

A second well-traveled route to social retirement is disability benefits. All nations reviewed here, especially Sweden, Germany, The Netherlands, the United Kingdom, and Australia, face 
important challenges in both eligibility for disability pensions and benefit generosity. When unemployment is high and workers are near retirement, the idea of relaxing the criteria for disability is attractive to public officials.

A third way that public social benefit policy can directly affect early retirement is by means of early retirement benefit receipt. Most nations have arrangements under which qualified workers can elect early receipt at a reduced benefit level. In Germany, early retirement with full benefits is allowed in specific cases. While this third way is the easiest to affect via public policy, no country, except Germany, has recently changed these rules. As suggested by Theeuwes (1997), to study the retirement decision in old age, at least two (disability and early retirement) and perhaps all three (including unemployment) types of benefits need to be simultaneously evaluated.

A separate retirement determinant mentioned earlier is the occupational pension. Here employers (in the private and public sector) can exert considerable influence over job departure, especially when the pension is of the defined benefit (DB) type. In Canada, the United Kingdom, The Netherlands, and the United States, employer pensions often affect departure from the firm. However, while employer pensions are "work-conditioned" from the firm's point of view, there is no penalty for work in alternative employment. Workers accepting pensions from specific employers often take new jobs, and combine earnings and retirement benefits.

With respect to public retirement benefits, most nations administer a "retirement test" to determine beneficiary status. These range from Germany, where there is a substantial penalty for work, to the United Kingdom, where there is no work penalty. In Sweden, partial public pensions can be mixed with part-time work, and in the United States where there is a substantial earnings disregard (about $\$ 8,600$ per year for those aged 62 to 64 , and $\$ 13,500$ for those aged 65 to 69 ). 
In our empirical work below, we will see that work and retirement are frequently combined in some of these countries.

\section{Conclusion}

Among the seven nations we are studying here, there is both considerable similarity and substantial difference across nations. Every nation is facing a severe demographic challenge, some more than others. Yet every nation has one or more avenues for early retirement at the same time that life expectancy at older ages and overall economic well-being among the aged are increasing. One solution to the fiscal crisis of old age is to try to keep potential beneficiaries employed and to limit these avenues of labor force retreat.

The first step in formulating these policies is to see how workers and their families mix earnings and other sources of income around retirement ages. In the sections below, we demonstrate the complexity of defining retirement within any one country and across countries. We will follow the lead of Smeeding (1992), and use several definitions of "retirement" to examine retirement patterns across nations. We will see to what extent beneficiaries mix employment and social pensions and will investigate the impact of retirement on one aspect of economic wellbeing-poverty.

\section{Data and Definitions}

The data used in this paper come from the Luxembourg Income Study (LIS), a social science database that now covers 25 nations and 75 databases. ${ }^{2}$ The LIS countries and data years used in the paper are Australia (1985-1986 and 1989-90), Canada (1991, 1994), The Netherlands (1987, 1991), Sweden (1987, 1992), the United Kingdom (1986, 1991), the United States (1986, 1994), and West Germany (1984, 1989). 
These data allow us to identify separately earning and retirement income receipt for family heads, spouses, and other adults. ${ }^{3}$ However, one should remember that these data provide only time-specific cross-sectional "snapshots" of several measures of "retirement" at particular points in time, or short trends in these snapshots. To fully analyze the dynamic process of retirement from a cross-national perspective, comparable panel data such as that used by Burkhauser et al. (1997) is necessary. Unfortunately, these panel data are currently available for only three of the seven nations studied here, and even these are limited in scope to three to ten years of recent retirement behavior.

The major variables used to define retirement here and elsewhere are lack of earnings (labor force departure) and/or receipt of retirement income. Earnings include cash compensation from all types of employment (wages and salaries, self-employment, and farming). Retirement income includes all forms of social pensions, occupational pensions (from private or public employers), and government employee pensions. Retirement income is also defined here to include long-term disability pensions and other types of special "younger age" pensions offered to workers by enterprises and/or governments. While long-term disability benefits could be excluded, they serve as an early retirement device in many nations. In fact, the inclusion or exclusion of long-term disability income can create large differences across nations. For instance, the inclusion of longterm disability benefits and unemployment insurance as retirement income, raises the fraction of Australian heads aged 55 to 59 having retirement income from 29 to 39 percent. In The Netherlands, the proportion of heads in this same age range with retirement income rises from 47 to 65 percent once disability is included. The widespread use of disability benefits as a bridge to retirement income in most of the nations studied here is widely acknowledged (Haveman, Halberstadt, and Burkhauser 1984; Burkhauser et al. 1997; Aarts and DeJong 1992). It is 
important to note that our retirement income definition does not include short-term worker disability benefits, nor does it include means-tested "welfare" or "special assistance" benefits (except in Australia where all "old age pensions" are income tested). These income components are, however, included when determining poverty status.

We could also include unemployment insurance as a type of retirement income. However, because unemployment insurance is received by many older workers who will indeed return to work, we are hesitant to label it as retirement benefit and have not done so here. ${ }^{4}$

All of our analyses define the retirement status of households (or families) based on the earnings, income, and characteristics of the "head" of the household (which is the male in two adult units) or based on the incomes of the entire household. Households are generally defined to include all persons related by blood, marriage, or adoption plus single persons living alone or with or without other unrelated persons (Coder 1990). Female heads, which are included only in our poverty analyses, may therefore be single individuals or women living with children or with other adults to whom they are not married.

While retirement may be an individual phenomenon, social policy analysts are generally concerned about the way that retirement effects household economic status. Since lack of earnings or receipt of retirement income by an individual head may nor may not coincide with low family income, we concentrate on persons in families as the main unit of analysis in all comparisons of family economic status. To measure poverty or low income, we adopt a relative measure based on equivalence adjusted disposable cash income for the entire nation. Disposable cash income includes all forms of money income received by the family including retirement income, earnings, and all forms of transfers and property income net of direct income and payroll taxes. All family disposable incomes are normalized to the income of a three-person family using an equivalence 
scale with family size adjustments, where equivalent disposable income (EDPI) is agreed to unadjusted disposable income $(D P I)$ divided by household size $(S)$ raised to the exponent, E:

While values of E may range from 0 (full economies of scale) to 1 (zero economies as measured by per capita income), we follow recent practice and set $\mathrm{E}=.5$ (Atkinson, Rainwater, and Smeeding 1995). Poverty is therefore defined as all persons living in families with adjusted incomes less than half of the national median adjusted income, the most common relative poverty definition used by OECD, the United Nations and other bodies (e.g., Rainwater and Rein 1992; Foerster 1993; Smeeding 1997).

\section{Results: Differences in Retirement Patterns by Retirement Definition, Work After Retirement, and Poverty}

Here we take a look at retirement from a family income perspective. We first look at the effect of various retirement definitions on the level and trend in retirement. Next we ask if zero earnings means receipt of retirement income and conversely the ways that retirement income and work stoppage are mixed. Then we take a closer look at the relationship between work and retirement in general, and self-employment in particular. We close by examining the relationship between retirement and poverty.

\section{Retirement Definitions}

We begin by investigating families ranked by age of head and head's earnings and retirement income patterns in seven countries using the latest data we have available for each country (Table 2). Three potential definitions of retirement are presented: families with heads having zero earnings (Part I), families with heads receiving retirement income (Part II); and families with heads having both zero earnings and receiving retirement income (Part III). We then create the same table with income and earnings characteristics based on all members of the 
household (Table 3). These two sets of figures together tell us the differences between basing the definition of retirement on heads' earnings and income characteristics versus household characteristics. The former is more akin to the usual treatment of retirement as a personal phenomenon while both provide a way to examine the welfare (or well-being) consequences of retirement and its impact on families.

The first definition of "retirement" is lack of earnings (Table 2, Part I). Because not all LIS datasets measure head's self-declared labor force status, it is not possible to discern whether the family with a nonearning head is unemployed, retired or other. The older the head, the more likely the head is to be retired, but the correlation of not working and receipt of retirement income by the head or by any other household member is far from perfect.

The second definition of retirement is based on receipt of retirement income (Table 2, Part II). The head may or may not have a job while receiving retirement income. Similarly, in the household format, a head may be still working while someone else receives retirement income (Table 3, Part II). For those interested in the budgetary cost of retirement to society (in the case of retirement outlays), this definition of retirement may be preferred.

If one wants to be more certain that a head is fully retired, one could count only families whose heads have zero earners and receive retirement income (Table 2, Part III), or at households in which no one is working but at least one person is receiving retirement income (Table 3, Part III). This definition produces many fewer retired families, especially in the younger age ranges, as one might expect. Of course, we cannot tell if the head will ever return to work. Analyses of panel data in the United States indicate that less than 10 percent of those out of the labor force for at least two years will return to work (Quinn, Burkhauser, and Myers 1990). Comparable German panel data indicate a much lower fraction of Germans, about 5 percent, will return to work (Merz 
1990). For analyses of economic well-being, e.g., poverty status and the adequacy of retirement income, this definition may be the preferable one.

Retirement Levels. The entries in Table 2 display considerable heterogeneity across countries. One straightforward conclusion here is that retirement, however defined, increases with age. Retirement is most likely in The Netherlands, particularly in the aged 55 to 59 and aged 60 to 64 categories, even when we impose dual criteria (Part III). Even with The Netherlands excluded, the intercountry variation is large, particularly in the aged 55 to 59 and aged 60 to 64 brackets. Excluding The Netherlands, between 20 percent (Canada and Germany) and 28 percent (Sweden) of all heads aged 55 to 59 received retirement income (Part II). In the same group, however, less than 18 percent of the aged in the United Kingdom, and even fewer in all other nations (except The Netherlands), have both stopped work and are receiving retirement income. Excluding Australia, at least 40 percent of all heads aged 60 to 64 in every country receive retirement income (Part II). But the fraction who also have zero earnings in this older bracket varies between 27 percent (Sweden) and 39 percent (Canada and Germany), except for The Netherlands, where a full 73 percent of household heads aged 60 to 64 have no earnings and receive retirement income.

Focusing on the most strict definition of retirement (Part III of Table 3), Sweden and Australia appear to have "later" retirement patterns than do the other nations. The United States retires later at older ages (e.g., aged 65 to 74) but average or above at younger ages (aged 60 to 64). ${ }^{5}$ The Germans start with low retirement in the youngest age group, but then quickly move to above average rates. The Dutch are, within all age groups, most likely to be fully retired, with the British second at the lowest (aged 55 to 59) and older (aged 65 and older) retirement ages.

If we shift focus to include the incomes of all household members, the situation is a bit different (Table 3). ${ }^{6}$ The fractions with zero earnings are lower because we count other members' 
earned income (Part I), and the fractions with retirement incomes are higher because we count the retirement incomes of others as well (Part II). The net result (Part III) is a lower fraction of fully (doubly) retired households at all ages. In the critical age period of 60 to 64, only between 18 percent (Sweden) and 37 percent (the United Kingdom) of households have no earners and receive retirement income compared to numbers generally about 50 percent higher in Table 2 . Taking the household resource definition, the most interesting pattern in Table 3 is found among those aged 65 to 74, and therefore beyond the age of normal retirement in all these countries. Here we find that over 70 percent of households are retired by both definitions in Germany and the United Kingdom, between 60 and 70 percent in Canada and Sweden, but only 52 percent in the United States and 44 percent in Australia. Yet in all but Australia, over 90 percent of these households have someone who is receiving retirement income (Part II of Table 3). This means that even if individuals do not do well mixing retirement income with work at older ages, households tend to do much better. We return to this issue below.

Trends. Next we turn to changes in these measures between a beginning year (mid1980s) and an ending year (1990s except for Germany (1989)) for each nation (Table 4). We concentrate on the trends facing heads here because the trend in households change is very similar.? The trend is presented as the absolute change in the variable of interest from the most recent to the earliest year. A value of -0.3 for Australian heads aged 55 to 59 with zero earnings indicate that in 198540.1 percent of Australian heads had zero earnings (Smeeding 1992, Table 4.1), compared to 39.8 percent in 1989 . Hence 0.3 percent fewer heads had zero earnings in 1989. It follows that positive values mean more of the given characteristic while negative values mean less.

Patterns of labor force change for heads (Table 4, Part I) indicate retreats from work at all ages for Canadians and the Dutch especially at ages 60 to 64 in Canada and ages 55 to 59 in The 
Netherlands. In Australia, the reverse was true at all ages. The other countries show mixed results. $^{8}$

More disturbing from a policy perspective, receipt of retirement income (Part II) is rising in some age brackets everywhere but in the United Kingdom. Together these translate into a higher fraction of heads with zero earnings and retirement income (Part III) at critical younger ages in Canada, The Netherlands, and Germany. There were only modest increases in the United States and in Sweden over this period.

\section{Relationship between Earnings and Receipt of Retirement Income}

The next two tables (Tables 5 and 6) are designed to show that zero earnings among older heads does not always infer receipt of retirement income (Table 5), and vice versa (Table 6). ${ }^{9}$ We perform these analyses for heads (Panel A) and for households (Panel B) in each table. In each of these cases, the variance is large across all countries. Hence, absence or presence of one characteristic should not be used to infer another, particularly for those heads between aged 55 and 64.

Except in The Netherlands (58 percent) and Sweden (65 percent), the majority of heads aged 55 to 59 with no earnings are not receiving retirement (including disability) income. The correlation improves with age, and by age 65 , nearly all household heads without earnings are receiving retirement benefits (Table 5, Panel A). In Panel B, we find that if there is no earned income in the entire household, retirement income is more prevalent than if we focus on the head alone. Beyond age 60, 80 percent or more of households with zero earnings also have retirement income everywhere but in Germany.

The fraction of heads for whom receipt of retirement income means total work stoppage is quite varied, with Sweden and the United States with the lowest numbers (Table 6). In Sweden, 
the majority of heads aged 55 to 65 with retirement income still work; in the United States, between one-third and one-half do. In the other nations, the vast majority of those receiving retirement income no longer work.

Once the earnings of other household members are taken into account (Panel B), the pattern changes, with the fraction of households without earners falling in all nations. For instance, at aged 60 to 64, only in Australia and in Germany do we find retirement income receipt means no earned income for half or more of the families.

This means that a large fraction of retirees, especially younger ones, continue to work. This pattern is most clearly seen in Table 7 which is derived directly from Panel A of Table 6. Work and retirement income are most often combined in Sweden and the United States where parttime retirement (Sweden) and a large earnings disregard (United States) encourage mixing work and retirement. In Germany, the United Kingdom, and The Netherlands, there is less mixing of work and retirement among household heads. The message from this final table is an important one. Nations such as Germany and The Netherlands where still larger pension outlays loom in the near future could perhaps help reduce these outlays by encouraging work among otherwise retired heads. Given recent changes in life expectancy and the changing nature of work from manufacturing to service sector jobs in all of these nations, there is room for policy to further increase work at older ages.

\section{Does Retirement Mean Impoverishment?}

Perhaps the most important question asked about "retirement" in a family/household context is its effect economic well-being and on poverty status. Regardless of whether they are pushed or pulled out of the labor market, are retirees significantly more (or less?) likely to be among the low income population? To examine this question, we prepared a final table that shows 
the rate of low income or poverty among persons living in older families (Table 8). As mentioned earlier, poverty is defined as living in a family with adjusted income less than half the median adjusted income for all families. Estimates are made for three groups of persons: all persons in the age group (Part I); all persons living with heads having retirement income (Part II); all persons living with heads with both retirement income and zero earnings (Part III). Finally, we have added a column for those aged 19 to 54 so that we can compare poverty status of the old to other adults.

The first result to note is that poverty varies more across countries than across age groups within countries (Table 8, Part I). For instance, the differences between the United States (or the United Kingdom) overall poverty rates and the German (or Swedish) rates are greater than the differences between the working age and older age poverty rates in each of these countries. Only in Australia (with a means-tested retirement program) and among Germans aged 55 to 59 are persons in families with retirement income (Table 9, Part II) more likely to be poor than is the entire population. In most age/country cells, poverty rates are actually lower for those with retirement income than are those for the population at large. This is less true among the group with retirement income and zero earnings, suggesting that combining work and retirement benefits may be a useful strategy to avoid poverty. In some nations, pockets of high poverty exist among those without earnings and with retirement income at younger ages (which is probably disability income in many cases). but poverty rates plummet around normal (age 65) retirement age. Canada, Germany, and The Netherlands have this pattern. This suggests that besides work, other social programs (e.g., disability, early retirement, and unemployment) also provide a "bridge" to full retirement. In other high poverty nations, Australia, the United Kingdom, and the United States, poverty is high among workers and nonworkers alike at older ages. We conclude that poverty in old age depends on country of residence as well as work status. 


\section{Conclusion and Policy Implications}

Several points emerge from this overview of retirement patterns in these seven countries:

${ }^{\circ}$ Retirement has many meanings, and the number of retired workers in a country depends critically on the definition chosen. Stereotypical retirement, a one time movement from full-time work to complete labor force withdrawal, is only part of the story in these developed nations. Many individuals nearing traditional retirement age supplement their retirement income with labor market earnings, and even more households combine the two (see also Palme 1990; Clark and Ogawa 1992). The most notable exceptions are Germany (at older ages) and The Netherlands (at all ages), where mixing the two sources of income is less common. These behavioral differences are related to institutional differences in the impact that earnings have on the size of retirement benefits. Sweden, the United States and Canada appear to have the less restrictive earnings tests, and older workers respond accordingly.

${ }^{\circ}$ Brief trends in retirement patterns between the mid-1980s and the early 1990s (with slightly different beginning and ending dates in the different countries) display no common pattern. Canada and The Netherlands show the most movement toward continued early retirement, under either the "earnings" or the "retirement income" criterion. Australia is the only country to show delayed retirement over time at all ages, using the "no earnings" definition, but a more ambiguous pattern appears when receipt of retirement income is used. The United States shows very little change since 1986, consistent with the labor force participation rate data in Figure 3. The other countries tend to show different patterns at different ages.

- Social programs can be very effective in preventing poverty among the retired. In the United States, the poverty rate among the elderly was cut in half in only seven years (from about 
30 percent and twice the national average in 1967 to 15 percent in 1974) following large increases in real Social Security benefits in the interim. Sweden (at all ages), Germany and The Netherlands (at aged 60 and over) and Canada (at aged 65 and over) have been successful in nearly eliminating poverty among the retired. In the other countries, although the absolute levels of poverty are higher, retirement of the head is not necessarily associated with an increase in the probability of poverty. Our analyses, however, say nothing about the likelihood of being "near-poor." In the United States, the United Kingdom, and Australia, the elderly are more likely than the rest of the population to hover just above the poverty thresholds (Smeeding 1997).

- Finally, encouragement of gradual or partial retirement—-the combination of retirement income and earnings - may be a good idea for several reasons. It may be better for the personal well-being of many retirees than an abrupt change. Although we did not explore this issue in this paper, there is evidence, in the United States at least, that many older retirees who are out of the labor force would like to be working (often only part-time), and that many workers would like to work longer than they think they will (McNaught and Barth 1993; Quinn and Burkhauser 1994). In addition, combining the two is good for the household's financial well-being. Poverty rates are highest where retirement income was combined with zero earnings. In the United States, poverty rates are substantially higher among those elderly without labor market income. Finally, delayed retirement may relieve the fiscal pressures on governments and economies, by reducing the benefits during the intermediate periods of those who successfully blend work and retirement. 


\section{References}

Aarts, Leo and Philip DeJong. 1992. "Early Retirement of Older Male Workers Under the Dutch Social Security System.” In A.B. Atkinson and M. Rein (eds.), Age Work, and Social Security. New York: MacMillan.

Atkinson, A.B., Lee Rainwater, and Timothy M. Smeeding. 1995. Income Distribution in OECD Countries: The Evidence from LIS. Paris: Office for Economic and Cooperative Development.

Boivenberg, L. and A. van der Linden. 1997. "Pension Policies and the Aging Society," OECD Observer, 205: 10-14.

Burkhauser, Richard V., Debra Dwyer, Maartin Lindeboom, Jules Theeuwes, and Isabel Woittiez. 1997. "Health, Work, and Economic Well-Being of Older Workers Aged 51 to 61: A CrossNational Comparison Using the United States HRS and the Dutch CERRA." Working Paper, Center for Policy Research, The Maxwell School. Syracuse, NY: Syracuse University, mimeo.

Clark, Robert and Naohiro Ogawa. 1992. "The Effect of Mandatory Retirement on Earnings Profiles in Japan," Industrial and Labor Relations Review, 45(2): 258-266.

Coder, John. 1990. “Technical Issues,” Luxembourg Income Study Newsletter, II(1) (April): 57.

deTombeur, C. 1994. “LIS/LES Information Guide,” LIS Working Paper \#7. Luxembourg: Luxembourg Income Study, February.

Employee Benefit Research Institute. 1995. EBRI Data Book, 3rd edition. Washington, DC: EBRI.

Foerster, M. 1993. "Comparing Poverty in 13 OECD Countries: Traditional and Synthetic Approaches," LIS Working Paper \#100. Luxembourg: Luxembourg Income Study, October.

Haveman, Robert H., Victor Halberstadt, and Richard V. Burkhauser. 1984. Public Policy Toward Disabled Workers: A Cross-National Analysis of Economic Impacts. Ithaca, New York: Cornell University Press.

Kotlikoff, Laurence J. and David A. Wise. 1989. The Wage Carrot and the Pension Stick. Kalamazoo, MI: The W.E. Upjohn Institute for Employment Research.

McNaught, William and Michael Barth. 1993. The Untapped Resource. Final Report on The Americans over 55 at Work Program. New York: Commonwealth Fund, November.

Merz, Joachim. 1990. Tabular data provided to the author.

Office for Economic and Cooperative Development. 1996. Aging in OECD Countries: A Critical Policy Challenge, Social Policy Studies No. 20. Paris: OECD. 
Office for Economic and Cooperative Development. 1995a. The Transition from Work to Retirement, Social Policy Studies No. 16. Paris: OECD.

Office for Economic and Cooperative Development. 1995b. The Labour Market and Older Workers, Social Policy Studies No. 17. Paris: OECD.

Palme, Joachim. 1990. "Pension Regimes and Retirement: Age and Income in a Cross-National Perspective,” LIS Working Paper \#51. Luxembourg: Luxembourg Income Study, June.

Peterson, Peter G. 1996. Will America Grow Up Before It Grows Old? New York: Random House.

Preston, Samuel. 1996. "American Longevity: Past, Present, and Future," Center for Policy Research Policy Brief No. 7, The Maxwell School. Syracuse, NY: Syracuse University.

Quinn, Joseph F. 1997. "The Role of Bridge Jobs in the Retirement Patterns of Older Americans." In Philip deJong and Theodore Marmor (eds.), Social Security and the Labour Market. London: Avebury Publishers.

Quinn, Joseph F. and Richard V. Burkhauser. 1994. "Public Policy and the Plans and Preferences of Older Americans," Journal of Aging and Social Policy, 6(3) (Fall): 5-20.

Quinn, Joseph F., Richard V. Burkhauser, and Daniel A. Myers. 1990. Passing the Torch: The Influence of Economic Incentives on Work and Retirement. Kalamazoo, MI: W.E. Upjohn Institute for Employment Research.

Rainwater, Lee and Martin Rein. 1992. "Economic Well-Being among Men 55-64 Without Earnings-A Six Country Comparison." In A.B. Atkinson and M. Rein (eds.), Age, Work, and Social Security. New York: MacMillan.

Schmähl, Winfried 1991. "Changing the Retirement Age in Germany." Paper presented at the European Society for Population Economics Annual Conference, Pisa, Italy, June 6.

Smeeding. Timothy M. 1991a. "The Meaning of Retirement: Cross-National Patterns and Trends." In L. Rainwater, M. Rein, and F. Naschold (eds.), The Interplay between Social Policy and Labor markets. Armonk, NY: M.E. Sharpe, Inc.

Smeeding, Timothy M. 1991b. "Mountains or Molehills: Just What's So Bad About Aging Societies Anyway?" In J. Hubek (ed.), Consequences of Aging Societies for Individuals. Newbury Park, CA: Sage, pp. 208-220.

Smeeding, Timothy M. 1992. "Cross-National Patterns of Retirement among Men and Women in the Mid-1980s: Full Stop or Gradual Withdrawal?" In A.B. Atkinson and M. Rein (eds.), Age, Work, and Social Security. New York: MacMillan, pp. 91-114. 
Smeeding, Timothy M. 1997. "Financial Poverty in Developed Nations: The Evidence from LIS.” Fiscal report for the UNDP. LIS Working Paper \#155. Luxembourg: Luxembourg Income Study, April.

Theeuwes, Jules. 1997. "Work and Well-Being: The Experience of the Elderly in Europe." Paper presented to the Conference on Emerging Policy Issues on Aging in Asia and the Research Response, Taipei, Taiwan, January 13-15. Mimeo. The Netherlands: University of Leiden.

U.S. Bureau of the Census. 1993. An Aging World II, International Population Reports P95/923. Washington, DC: U.S. Government Printing Office. 
Figure 1

Overall Labor Force Participation Rates

for Men Aged 55-64 in 1995

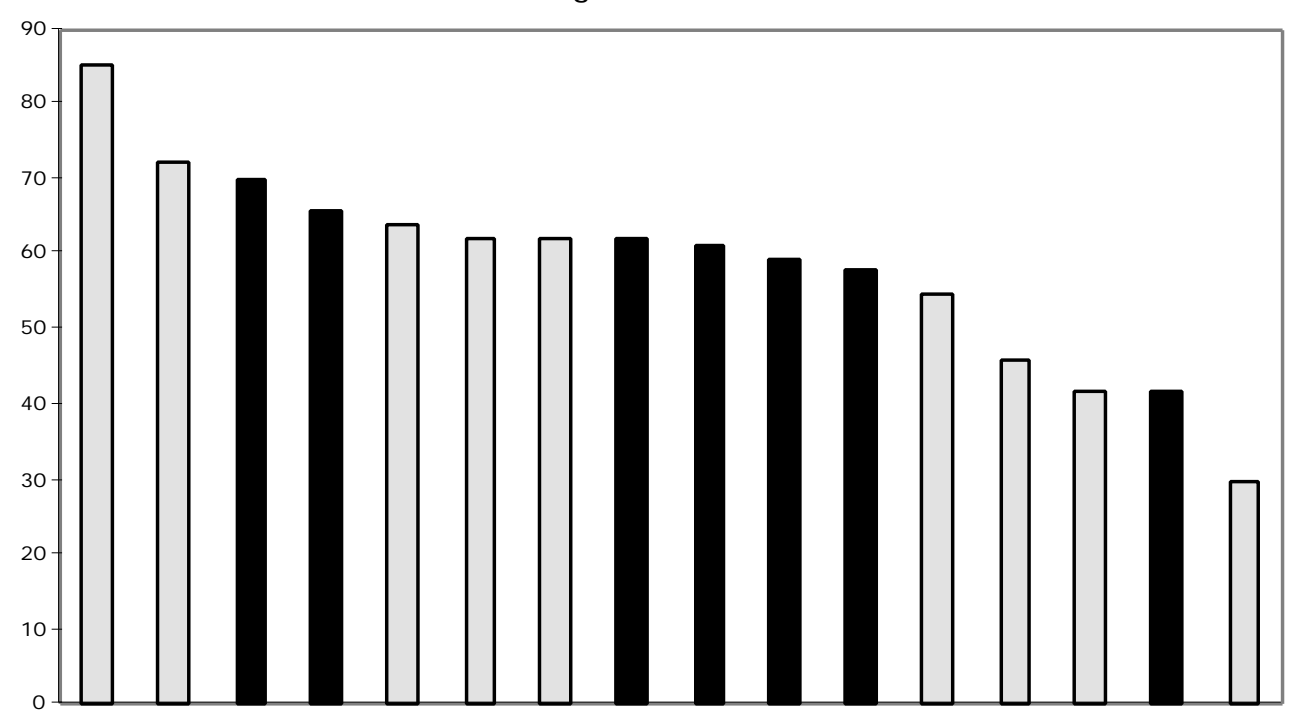

Source: OECD Labor Force Database 
Figure 2

Percentage of the Population Aged 65 or Over

Selected OECD Countries

$1990-2030$

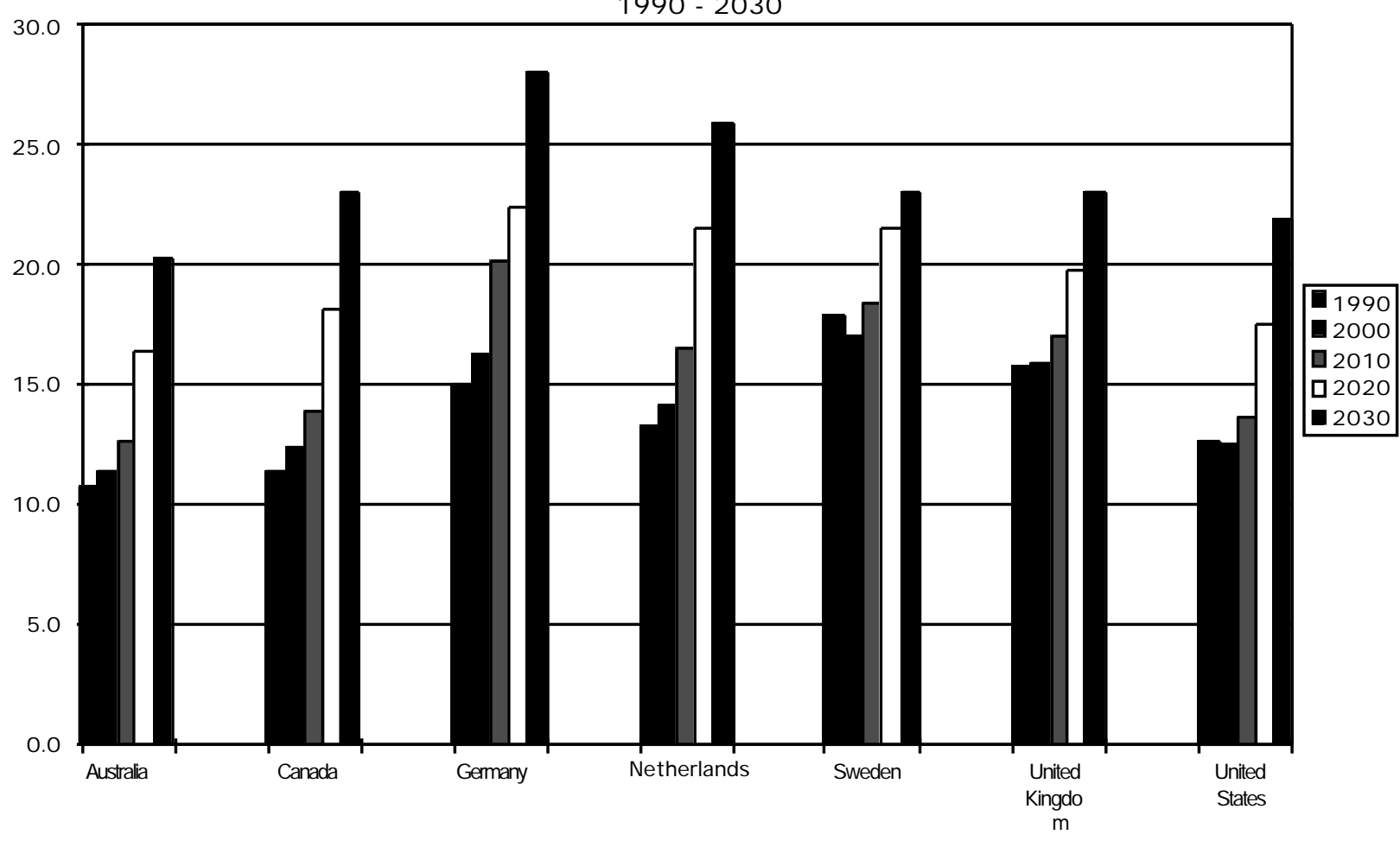

Figure 3a

Labor Force Participation Rates

Males, Age 55-59

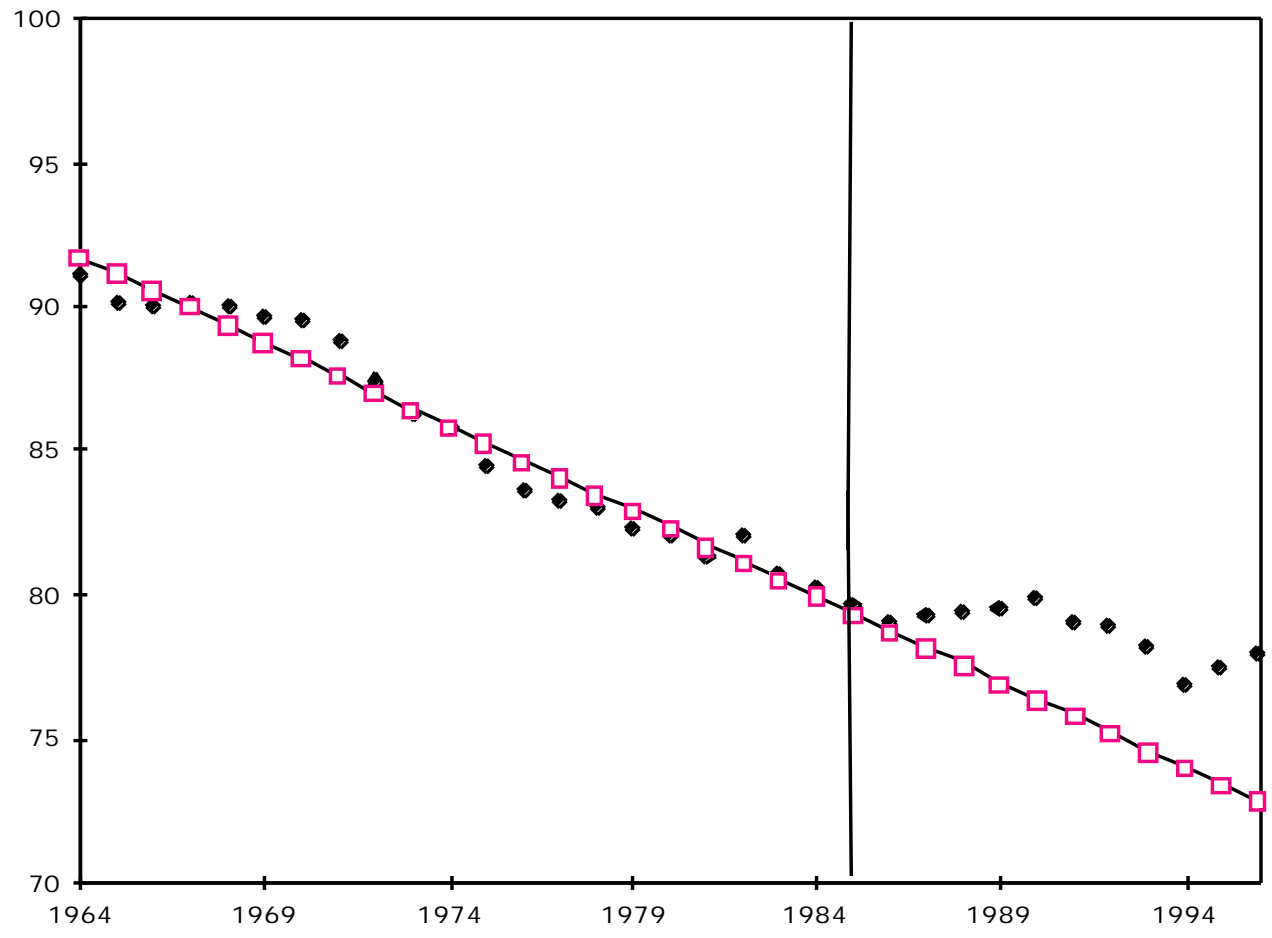

- M 55-59

-ㅁ-M 55-59 (fit) 
Figure 3b

\section{Labor Force Participation Rates \\ Males, Age 60-64}

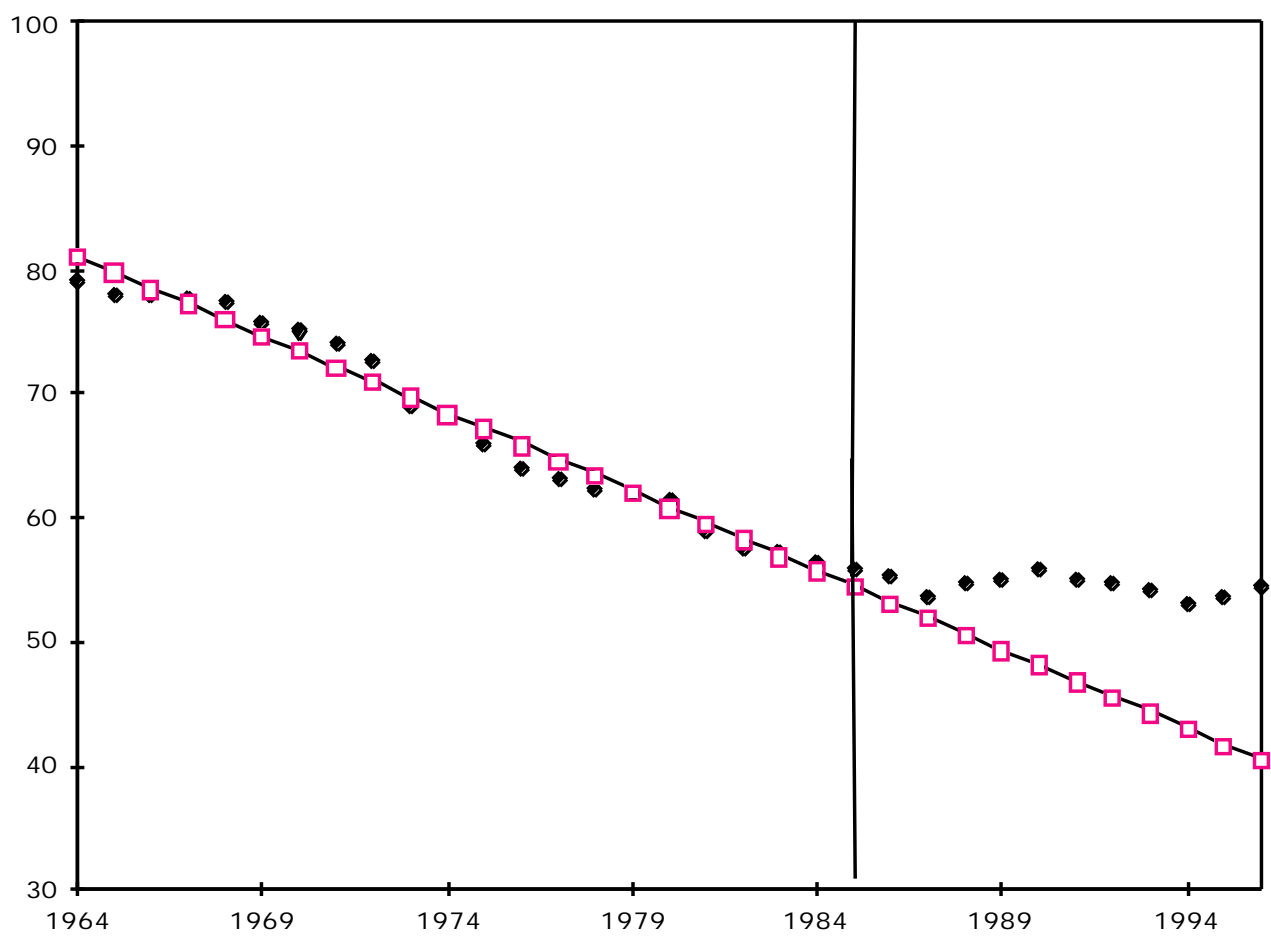

- M 60-64

Figure 3c

Labor Force Participation Rate

Males, Age 65-69

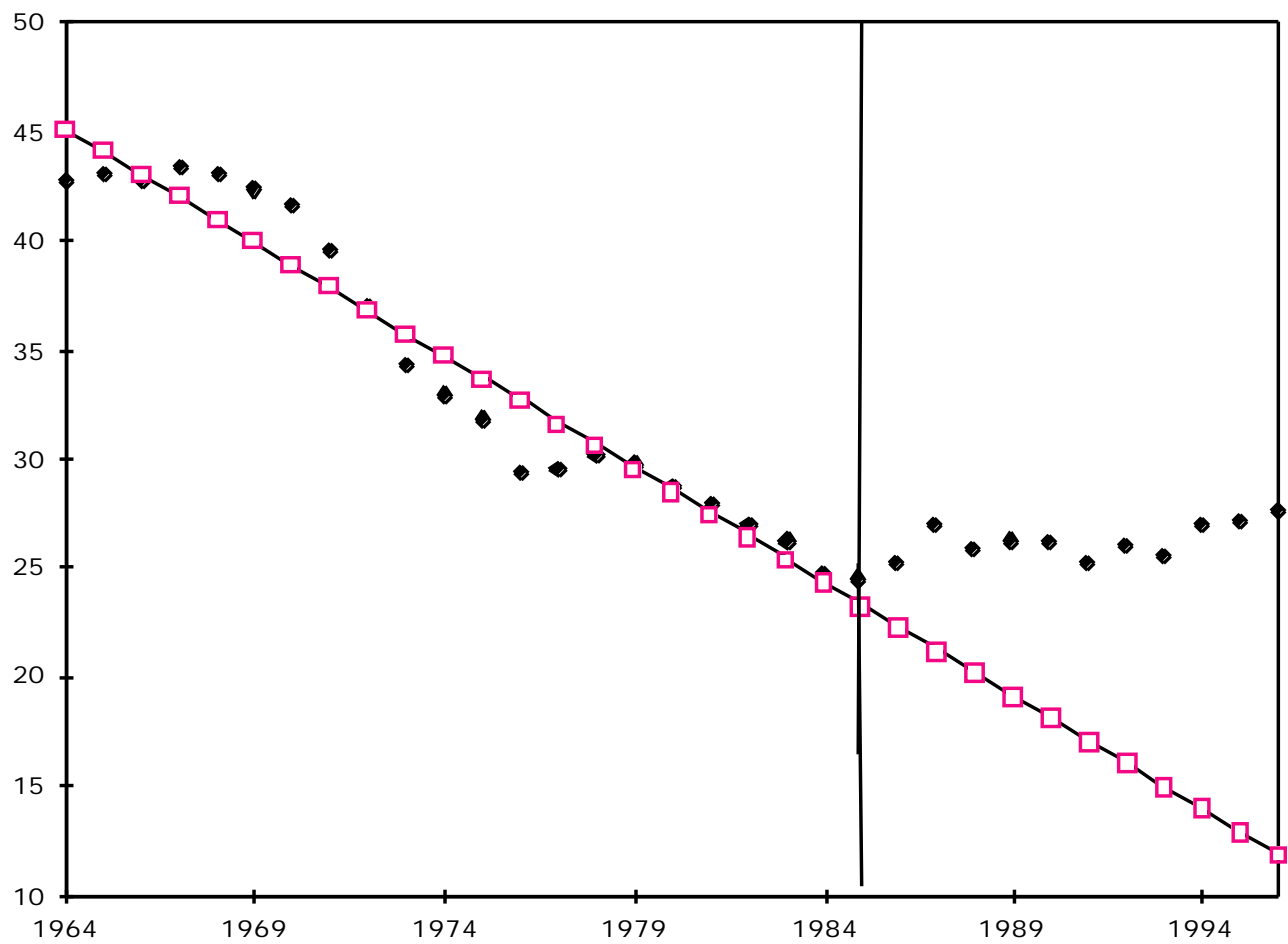

- M 65-69

- - M 65-69 (fit) 
Figure 3d

Labor Force Participation Rates

Males, Age $70+$

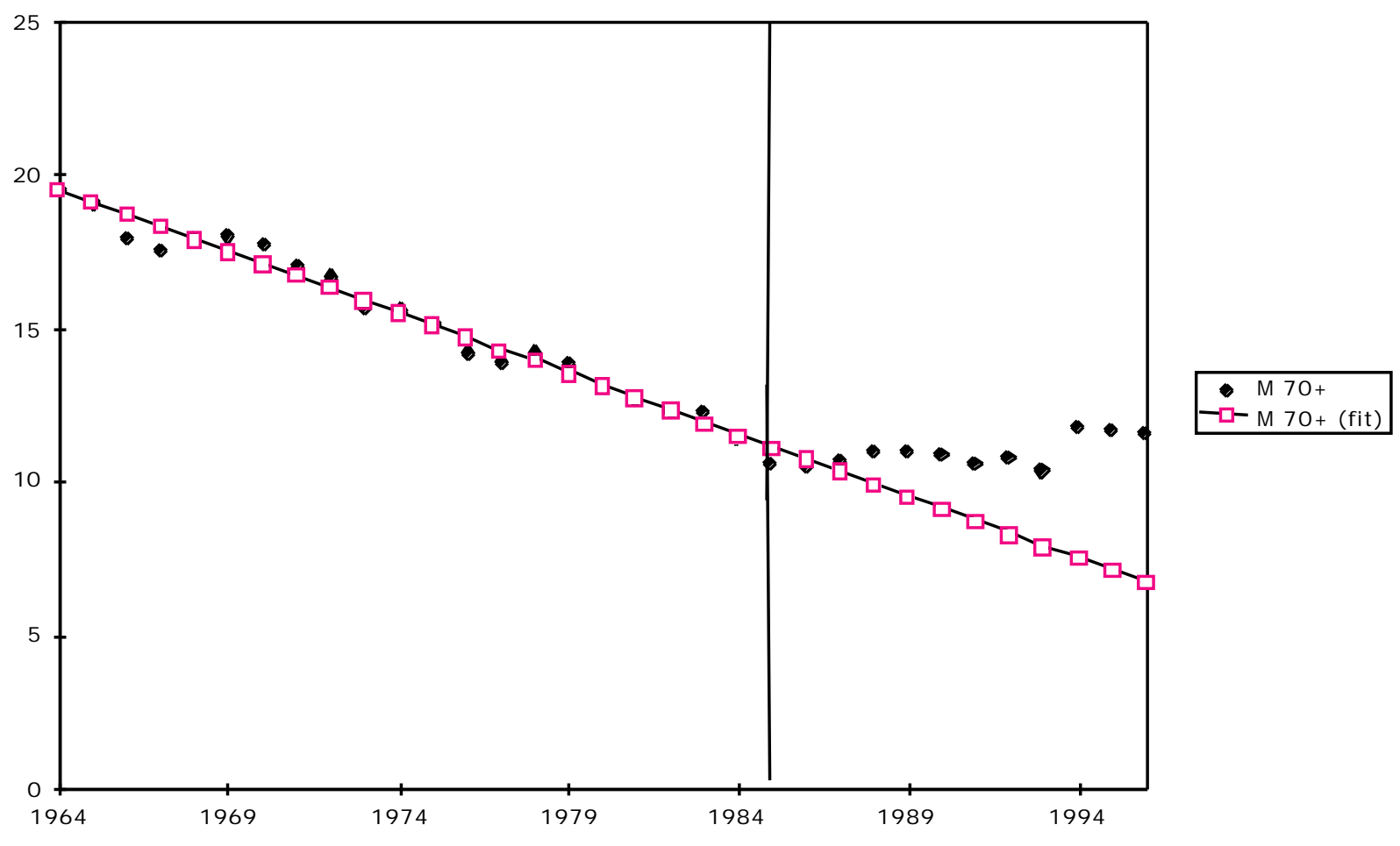




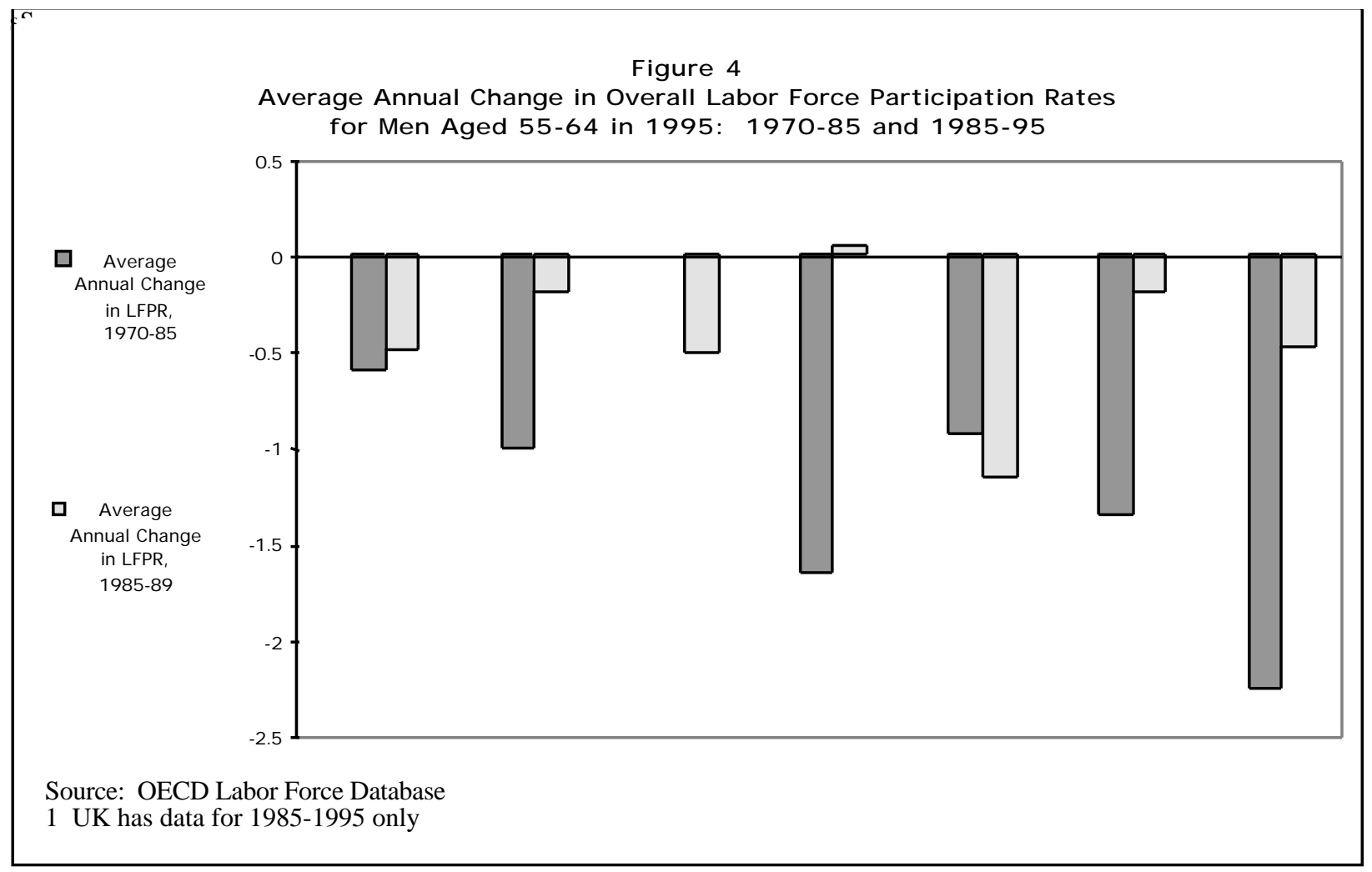


Table 1 Standard Age of Entitlement and Public Expenditures on Social Retirement: 1995 and 2030

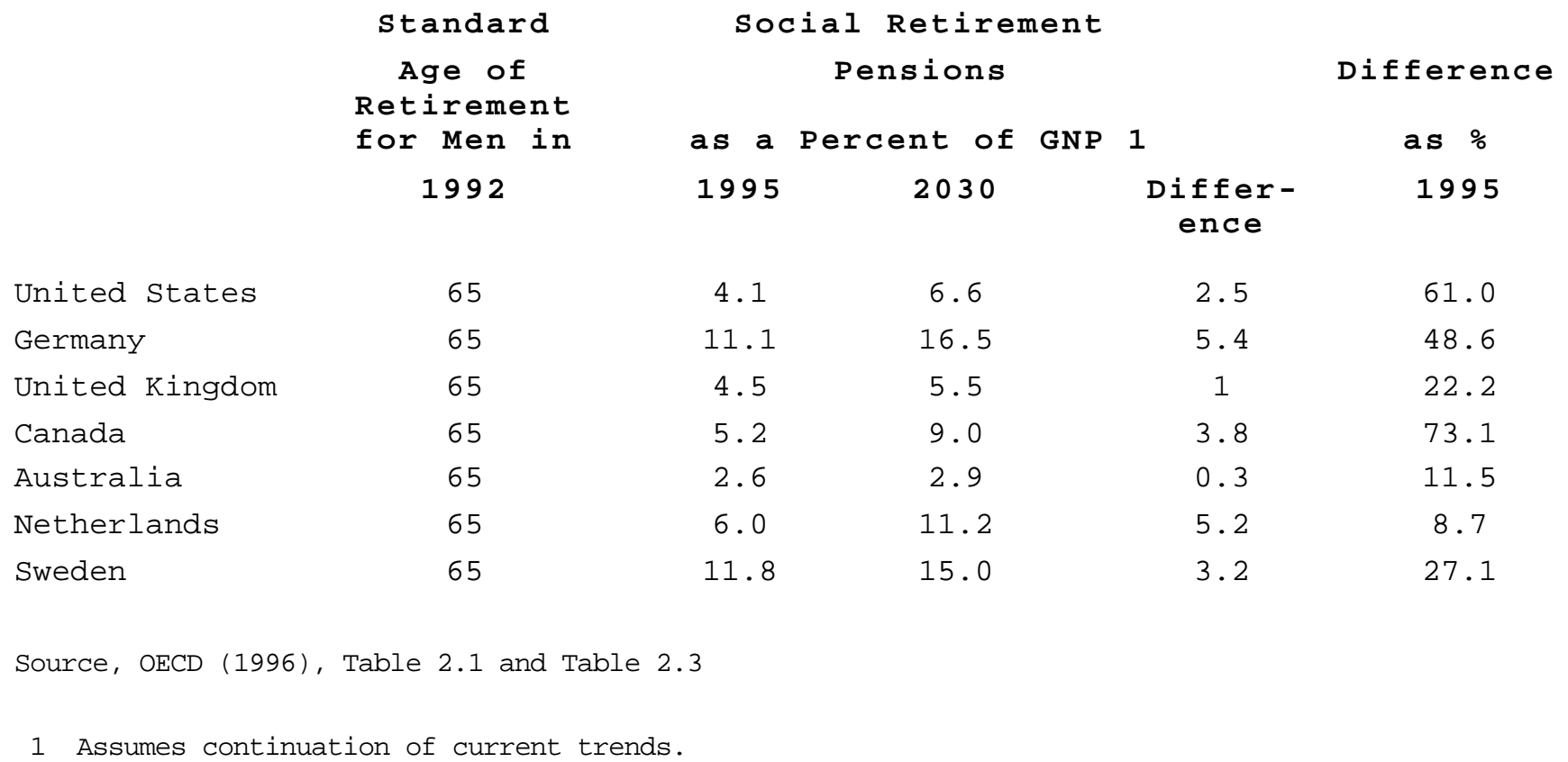

Source: OECD(1996), Table 2.1 and Table 2.3

1 Assumes continuation of trends. 
Table 2

Patterns of earnings and retirement incomel

defined by characteristics of family heads

(percentage persons living in families with heads having given characteristics)

Age

\begin{tabular}{|c|c|c|c|c|c|}
\hline & \multicolumn{3}{|c|}{ Age } & \multirow[b]{2}{*}{$75+$} \\
\hline & & $55-59$ & $60-64$ & $65-74$ & \\
\hline \multicolumn{6}{|c|}{$\begin{array}{l}\text { Part 1: All heads with zero } \\
\text { earnings2 }\end{array}$} \\
\hline Australia & 1989 & 39.8 & 58.3 & 89.9 & 98.2 \\
\hline Canada & 1994 & 32.7 & 57.7 & 90.6 & 99.1 \\
\hline Netherlands & 1991 & 65.1 & 88.5 & 99.2 & 100.0 \\
\hline Sweden & 1992 & 17.7 & 30.6 & 74.6 & 95.0 \\
\hline United Kingdom & 1991 & 48.5 & 66.8 & 94.4 & 98.4 \\
\hline United States & 1994 & 26.7 & 46.6 & 78.2 & 94.3 \\
\hline West Germany & 1989 & 34.6 & 56.1 & 96.1 & 99.7 \\
\hline \multicolumn{6}{|c|}{$\begin{array}{l}\text { Part I1: All heads with retirement } \\
\text { income3 }\end{array}$} \\
\hline Australia & 1989 & 21.2 & 33.6 & 59.1 & 82.9 \\
\hline Canada & 1994 & 19.9 & 49.9 & 99.1 & 99.1 \\
\hline Netherlands & 1991 & 46.4 & 78.7 & 99.1 & 98.8 \\
\hline Sweden & 1992 & 28.3 & 67.3 & 99.5 & 99.7 \\
\hline United Kingdom & 1991 & 24.0 & 39.9 & 98.7 & 99.7 \\
\hline United States & 1994 & 23.9 & 53.1 & 91.8 & 96.6 \\
\hline West Germany & 1989 & 19.7 & 47.7 & 91.7 & 94.1 \\
\hline \multicolumn{6}{|c|}{$\begin{array}{l}\text { Part III: All heads with both zero earnings and retirement } \\
\text { income } 4\end{array}$} \\
\hline Australia & 1989 & 16.9 & 30.0 & 55.4 & 82.3 \\
\hline Canada & 1994 & 12.8 & 38.6 & 89.9 & 98.3 \\
\hline Netherlands & 1991 & 37.7 & 73.3 & 98.2 & 98.8 \\
\hline Sweden & 1992 & 11.6 & 27.4 & 74.2 & 94.7 \\
\hline United Kingdom & 1991 & 17.6 & 34.4 & 93.2 & 98.2 \\
\hline United States & 1994 & 12.0 & 35.0 & 74.0 & 91.2 \\
\hline West Germany & 1989 & 14.2 & 38.9 & 88.7 & 93.8 \\
\hline
\end{tabular}

1Retirement income includes disability

payments.

2 Percentage of persons living in families with a head who has zero

earnings

during the survey period.

3 Percentage of persons living in families with a head who

receives

retirement

income.

4Percentage of persons living in families with a head who has zero

earnings and who receives retirement income. 
Table 3

Patterns of earnings and retirement incomel

defined by characteristics of family heads

(percentage persons living in families with heads having given characteristics)

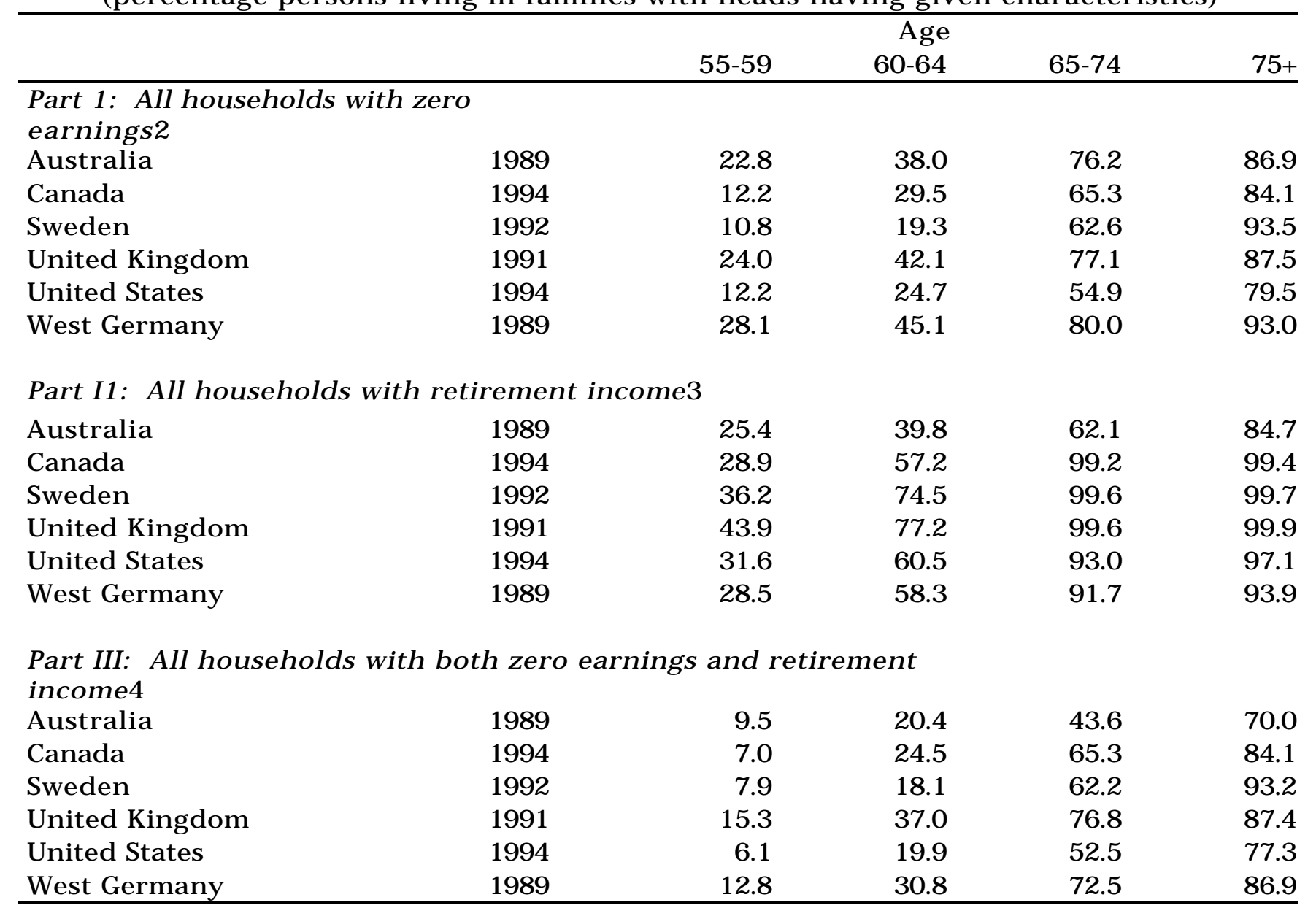

1 Retirement income includes disability payments. the

2 Percentage of persons living in families that have zero earnings during

survey period.

3 Percentage of persons living in families that receive retirement income.

4 Percentage of persons living in families that have zero earnings and that receive retirement

income. 
Table 4

Absolute change in patterns of earnings and retirement incomel

defined by characteristics of family heads

( $p$ ercentage persons living in families with heads having given characteristics)

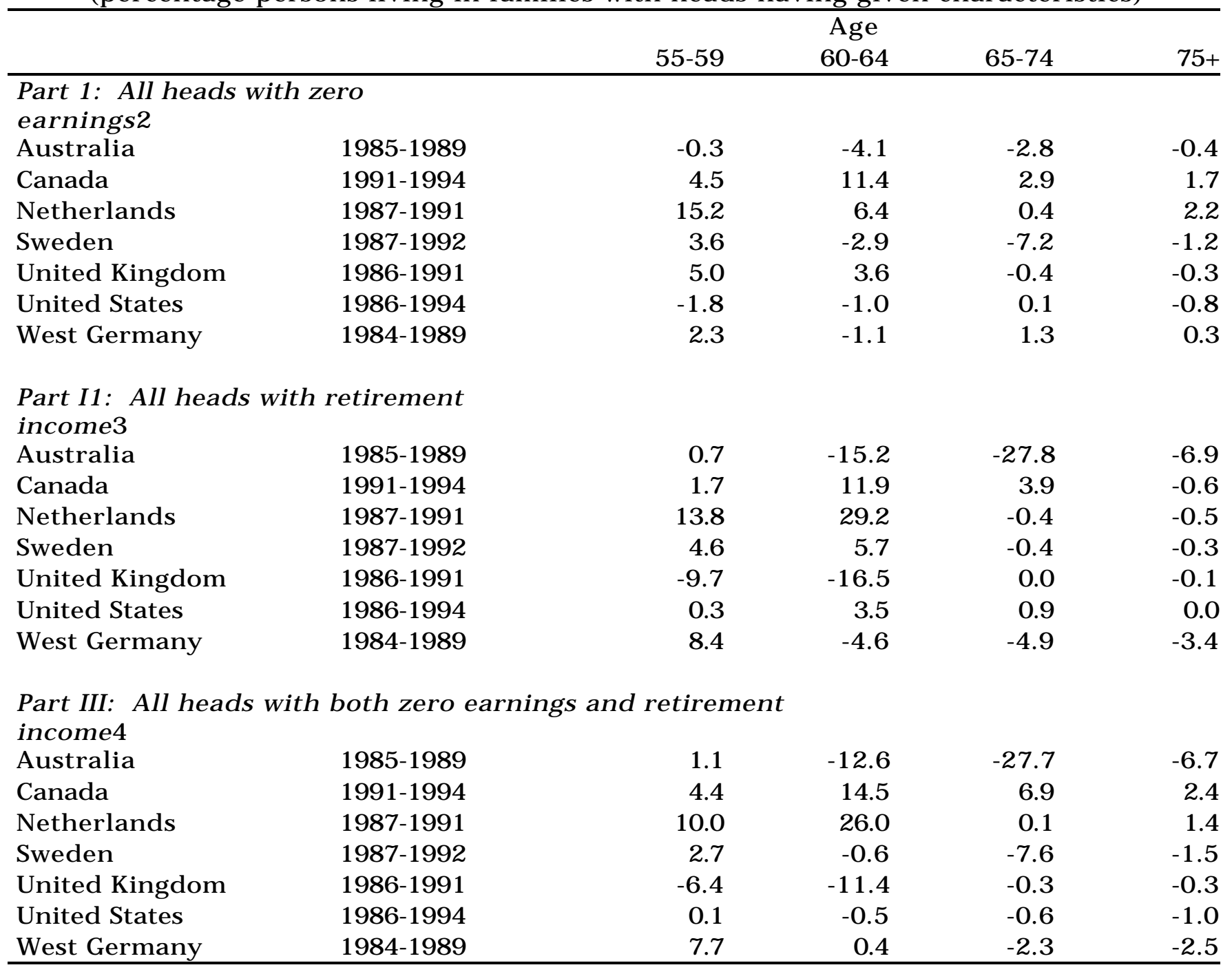

1 Retirement income includes disability payments.

2 Percentage of persons living in families with a head who has zero earnings during the survey period.

3 Percentage of persons living in families with a head who receives retirement income.

4Percentage of persons living in families with a head who has zero

earnings and who receives retirement income. 
Table 5

Zero Earnings and Retirement Income

Panel A: Do heads with zero earning always get retirement

income? 1

(percentage of heads with zero

earnings

who also have retirement

income) 2

\begin{tabular}{|c|c|c|c|c|c|}
\hline & & \multicolumn{3}{|c|}{ Age } & \multirow[b]{2}{*}{$75-1$} \\
\hline & & $55-59$ & $60-64$ & $65-74$ & \\
\hline \multicolumn{6}{|l|}{ All Heads } \\
\hline Canada & 1994 & 39.1 & 66.9 & 99.2 & 99.2 \\
\hline Netherlands & 1991 & 57.9 & 82.8 & 99.0 & 98.8 \\
\hline Sweden & 1992 & 65.5 & 89.5 & 99.5 & 99.7 \\
\hline United Kingdom & 1991 & 36.3 & 51.5 & 98.7 & 99.8 \\
\hline United States & 1994 & 44.9 & 75.1 & 94.6 & 96.7 \\
\hline West Germany & 1989 & 41.0 & 69.3 & 92.3 & 94.1 \\
\hline
\end{tabular}

Panel B: Do households with zero earnings always get retirement income? 1

(percentage of households with zero earnings who also have retirement income3)

\begin{tabular}{|c|c|c|c|c|c|}
\hline & & \multicolumn{3}{|c|}{ Age } & \multirow[b]{2}{*}{$75-1$} \\
\hline & & $55-59$ & $60-64$ & $65-74$ & \\
\hline \multicolumn{6}{|l|}{ All Households } \\
\hline Canada & 1994 & 57.4 & 83.1 & 100.0 & 100.0 \\
\hline Sweden & 1992 & 73.1 & 93.8 & 99.4 & 99.7 \\
\hline United Kingdom & 1991 & 63.8 & 87.9 & 99.6 & 99.9 \\
\hline United States & 1994 & 50.0 & 80.6 & 95.6 & 97.2 \\
\hline West Germany & 1989 & 45.6 & 68.3 & 90.6 & 93.4 \\
\hline
\end{tabular}

1 Retirement income includes disability payments.

2 Ratio of 'All heads with both zero earnings and retirement income' to

'All heads with zero earnings.'

3 Ratio of 'All households with both zero earnings and retirement income' to

'All households with zero earnings.' 
Table 6

Retirement Income and Work Stoppage

Panel A: Does retirement mean total work stoppage?

(percentage of heads receiving

retirement

incomel who also have zero

earnings) 2

\begin{tabular}{lcrrrr}
\hline & & Age & \\
& & $55-59$ & $60-64$ & $65-74$ & $75+$ \\
\hline All Heads & & & & & \\
Australia & 1989 & 79.7 & 89.3 & 93.7 & 99.3 \\
Canada & 1994 & 64.3 & 77.4 & 90.7 & 99.2 \\
Netherlands & 1991 & 81.3 & 93.1 & 99.1 & 100.0 \\
Sweden & 1992 & 41.0 & 40.7 & 74.6 & 95.0 \\
United Kingdom & 1991 & 73.3 & 86.2 & 94.4 & 98.5 \\
United States & 1994 & 50.2 & 65.9 & 80.6 & 94.4 \\
West Germany & 1989 & 72.1 & 81.6 & 96.7 & 99.7 \\
\hline
\end{tabular}

Panel B: Does retirement mean total work stoppage?

(percentage of families that receive retirement

incomel that also have zero

earnings) 3

\begin{tabular}{lccccc}
\hline & & Age & & \\
& & $55-59$ & $60-64$ & $65-74$ & $75+$ \\
\hline All Households & & & & & \\
Australia & 1989 & 37.4 & 51.3 & 70.2 & 82.6 \\
Canada & 1994 & 24.2 & 42.8 & 65.8 & 84.6 \\
Sweden & 1992 & 21.8 & 24.3 & 62.4 & 93.5 \\
United Kingdom & 1991 & 34.9 & 47.9 & 77.1 & 87.5 \\
United States & 1994 & 19.3 & 32.9 & 56.5 & 79.6 \\
West Germany & 1989 & 44.9 & 52.8 & 79.1 & 92.5 \\
\hline
\end{tabular}

1Retirement income includes disability

payments.

2 Ratio of 'All heads with both zero earnings and retirement income' to

'All heads with retirement income.'

3 Ratio of 'All households with both zero earnings and retirement income' to

'All households with retirement income.' 
Table 7

Do household heads combine work and retirement?

(percentage of persons living in families with heads receiving retirement

incomel where the head also has some earnings) 2

\begin{tabular}{lrrrr}
\hline & & \multicolumn{3}{c}{ Age of Head } \\
& & $55-59$ & $60-64$ & $65-74$ \\
\hline Australia & 1989 & 20.3 & 10.7 & 6.3 \\
Canada & 1994 & 35.7 & 22.6 & 9.3 \\
Netherlands & 1991 & 18.7 & 6.9 & 0.9 \\
Sweden & 1992 & 59.0 & 59.3 & 25.4 \\
United Kingdom & 1991 & 26.7 & 13.8 & 5.6 \\
United States & 1994 & 49.8 & 34.1 & 19.4 \\
West Germany & 1989 & 27.9 & 18.4 & 3.3 \\
\hline
\end{tabular}

1Retirement income includes disability payments.

2100 minus the ratio of 'All heads with both zero earnings and retirement 6) 
Table 8

Does retirement mean impoverishment?

(percentage of persons living in families with head having various characteristics defined as poor 1 )

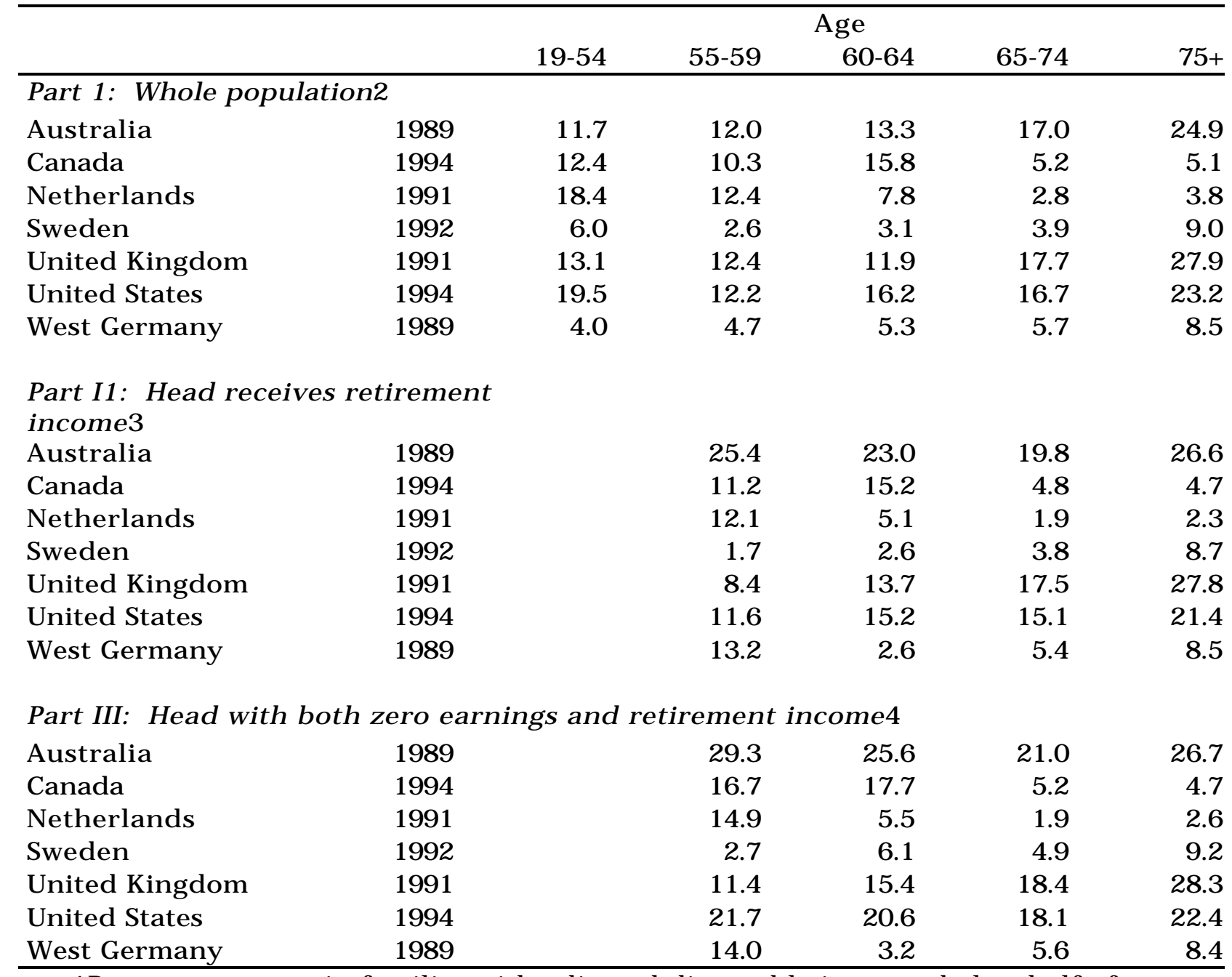

1 Poor are persons in families with adjusted disposable incomes below half of median adjusted disposable income (DPI) for individuals. Incomes are adjusted by $\mathrm{E}=0.5$

where adjusted DPI = actual DPI divided by household size (s) to the power E:

Adjusted DPI $=\mathrm{DPI} / \mathrm{sE}$.

2All persons in all families.

3 Persons in families whose head receives retirement income.

4Persons in families whose head has zero earnings and receives retirement income. 


\section{Endnotes}

A recent paper (Burkhauser et al. 1997, Table 3), indicates that in 1993 only 59 percent of Dutch men age 55, 44 percent of those age 59, and 16.8 percent of those age 61 , were still working in 1993. In the United States, in contrast, the figures were 77 percent at age 56, 69 percent at age 59, and 66 percent at age 61.

The outlays for some nations, e.g., The Netherlands, may be understated because disability, early retirement, and extended unemployment schemes are not taken into account here.

${ }^{2}$ LIS and the surveys used in this paper are briefly described in the Appendix and Appendix Table A-1. A more complete description of LIS can be found in deTombeur (1991).

${ }^{3}$ The terms "household" and "family" are used interchangeably. With the exception of Sweden, all persons living together are a family or household in this paper. The Swedish family definition is more narrow, treating all unmarried units aged 65 and over as separate persons. For an analysis of the older segment of the population, these nuances might take a marginal, though not significant difference.

$4 \quad$ Survey respondents may classify benefits as either unemployment or social retirement and thus, we are unable to determine "unemployment retirement" from standard "unemployment compensation" on most surveys.

${ }_{5}$ The earnings rules for Social Security benefits are more lenient in the United States for recipients aged 65 to 69 then they are far those aged 62 to 64 (a higher disregard, and then a smaller benefit loss ( 0.33 vs. 0.50$)$ for each dollar earned above the disregard). At age 70 , one can earn any amount without any reduction in Social Security benefits.

${ }^{6}$ Here we have excluded The Netherlands due to incomplete information on other household 
member incomes.

7 The trends in households are available from the authors.

8 It should be noted that both levels and trends in zero earnings in Tables 2 onward may differ from labor force participation rates and trends in Figures 1 and 4 because of differences in definitions, samples, and questions. For instance, most labor force surveys ask about current labor force status while income surveys measure earnings over the entire year.

${ }^{9} \mathrm{We}$ omit Australia in Table 5 because asking the questions we pose here do not make sense given the means-tested nature of their retirement income system. We omit The Netherlands in Panel B of both Tables 5 and 6 due to incomplete information on other household members' incomes. 